\title{
Os monumentos de Atenas na Lisístrata de Aristófanes
}

\author{
ADRIANE DA SILVA DUARTE \\ Departamento de Letras Clássicas e Vernáculas \\ Faculdade de Filosofia, Letras e Ciências Humanas \\ Universidade de São Paulo
}

\begin{abstract}
RESUMO: Na Lisistrata de Aristófanes, os monumentos de Atenas desempenham um papel importante para o desenvolvimento da trama cômica. Em maior evidência, a Acrópole, ocupada pelas mulheres, é parte essencial do plano da heroína para pôr fim à guerra fratricida entre espartanos e atenienses. Os homens, por sua vez, excluídos da cidade alta, fincam o pé na Ágora, tomando por símbolos de sua resistência o grupo escultórico dos tiranicidas e a amazonomaquia de Micon. Pretende-se aqui investigar as razões que levaram o semicoro masculino a escolher justamente esses monumentos para ilustrar sua fala.
\end{abstract}

PALAVRAS-CHAVE: Comédia grega; Aristófanes; Lisístrata; ágora ateniense; arte grega; amazonomaquia; tiranicidas; Crítios; Micon; tradição iconográfica.

O título deste artigo poderia sugerir que nele se empreenderá uma análise do papel da Acrópole e seus monumentos na trama de uma das comédias aristofânicas mais traduzidas e encenadas no século que se encerrou, marcado por grandes guerras, movimentos pacifistas, feminismo e revolução sexual - elementos freqüentemente associados a Lisístrata, embora sejam igualmente freqüentes os protestos dos helenistas contra o anacronismo subjacente. Não é da Acrópole, entretanto, que pretendo ocupar-me, mas começarei por traçar um breve quadro de sua importância no enredo da peça em questão, já bęm estabelecida e discutida por, por exemplo, Hulton (1972) e Loraux (1984, p. 159).

De fato, a tomada da Acrópole, juntamente com a deflagração de uma greve de sexo, faz parte dos planos de Lisístrata, a heroína, para pôr fim à guerra entre atenienses e espartanos. A falta de coordenação entre essas duas estratégias é visível ao leitor atento. No prólogo, a greve de sexo é enfatizada e a ocupação da colina sagrada citada apenas como um recurso secundário (vv. 175-179). No entanto, a partir do párodo e até o fim da parábase, só se tratará da invasão da Acrópole, tomada não só pelas mulheres mais velhas, mas também pelas jovens esposas que, pelo que fora acertado, deveriam estar em suas casas, preparandose para os jogos de sedução do tipo que Mirrine protagonizará mais tarde no palco (vv. 865 
ss.). A recusa das mulheres a Afrodite só será tratada nas cenas pós-parabáticas, quando a primeira parte do plano, por sua vez, cai no esquecimento (vv. 706 ss.).

Tratando dessa questão, Hulton sugere que a construção frouxa do enredo foi voluntária, uma vez que a existência da dupla estrutura favoreceria a exploração tanto da obscenidade, inerente ao gênero desde as suas origens rituais (tema da greve de sexo), quanto do conjunto arquitetônico da Acrópole, com toda a sua gama de significados mitológicos e históricos (tema da ocupação), tematizados principalmente na parábase. Nela, o ato de guerrilha das mulheres adquire sua dimensão simbólica, dada sobretudo pela famosa passagem em que o semicoro feminino relata sua estreita relação com os deuses e cultos representados na colina sagrada, especialmente os de Palas (vv. 640-647). Por outro lado, restringi-la somente a esse aspecto é perder de vista sua relevância para o desenvolvimento dos temas ligados à guerra entre os sexos. Cabe à parábase articular as duas partes do enredo e promover a transição entre elas, que não são de todo estanques, uma vez que a Acrópole, como frisou Loraux, está ligada aos jardins dos templos de Afrodite e Eros por passagens subterrâneas'.

É justamente na parábase que o semicoro masculino expressa sua reação à ocupação da Colina sagrada, que ele falha em recuperar na primeira metade da peça, e, para isso, faz referência a outros monumentos da cidade: o grupo escultórico dos tiranicidas (v. 633) e a Amazonomaquia de Micon (v. 678-79). Neste artigo, procurarei estabelecer qual o significado que esses marcos cívicos assumem no discurso masculino.

\section{O grupo escultórico dos tiranicidas}

Na parábase, a primeira sizígia epirremática vai repercutir a tomada da Acrópole e as implicações políticas e religiosas desse fato (vv. 614-635):

Dormir não é próprio de quem é livre!

Vamos, homens, dispamo-nos para esta briga!

Isto já está cheirando a coisas

muito sérias, acho eu.

E o cheiro que mais sinto é o da tirania de Hípias.

Temo muito que alguns lacônios

já estejam aqui na casa de Clístenes

e incitem essas mulheres odiosas aos deuses

a tomar dolosamente nosso dinheiro e o salário

do qual eu costumava viver.

Já é terrível que elas aconselhem os cidadãos

e, mulheres que são, tagarelem sobre o escudo de bronze

e tentem reconciliar-nos com os homens da Lacônia, nos quais se pode confiar quanto num lobo de goela aberta.

E elas tramaram contra nós visando a tirania. 
Mas sobre mim não exercerão a tirania, pois estarei de vigília e daqui para frente levarei o punhal no ramo de mirto, acamparei na praça do mercado, em armas, ao lado de Aristogíton, e nesta posição ficarei ao lado dele. Isso é o que vou fazer... Vou dar um soco no queixo desta velha, a quem os deuses detestam².

Os atenienses mais velhos interpretam a tomada da Acrópole como um fato político da maior gravidade, capaz de ameaçar a sua liberdade (v. 614). Há um cheiro de tirania no ar, dizem. E não se trata de qualquer tirania, mas da de Hípias, que, dos tiranos de Atenas, foi o que mais correspondeu ao estereótipo moderno do título. Nos últimos anos de seu governo, cercado por seguranças e isolado do povo, promoveu um regime de terror em que se sucediam prisões e assassinatos de supostos conspiradores. O princípio e o fim desse período negro da história de Atenas está intimamente associado à Acrópole. $\mathrm{O}$ assassinato de Hiparco, seu irmão, durante a procissão das Panatenéias, determinou o endurecimento do governo e, anos depois, foi da colina sagrada, onde buscara refúgio, que o tirano acabou expulso pelos Alcmeônidas, após cinco dias de resistência ${ }^{3}$. É natural, portanto, que o ato de ocupação das mulheres seja visto como uma tentativa de se restabelecer a tirania (v. 630) e não como um recurso extremo para impedir que o tesouro público fosse usado para financiar a guerra.

A participação dos espartanos no episódio também é lembrada com preocupação, pois, se de início ajudaram a derrubar Hípias, em seguida, para tentar instalar no poder a facção oligárquica, voltaram a ocupar a Acrópole, de onde foram tirados pelo povo em armas. Vem daí a desconfiança que eles inspiram no coro (vv. 628-629) e não apenas da guerra então em curso.

À luz desses fatos, a associação das mulheres de Atenas com as de Esparta só poderia soar aos ouvidos dos velhos como uma estratégia dos espartanos para se apoderarem da cidade. Clístenes, em cuja casa os agentes espartanos estariam infiltrados, é uma escolha óbvia para intermediar os contatos entre as mulheres e os inimigos, já que ele era frequientemente satirizado pelos comediógrafos por seus trejeitos efeminados (vv. 620-625). Ele é visto aqui como duplamente traidor: da sua pátria e do seu sexo. Mas também é homônimo do Alcmeônida que foi responsável pela aliança com os espartanos. Ao aludir ao Clístenes Alcmeônida, o coro adverte que qualquer pacto com os espartanos é perigoso, por mais nobres que sejam as razões que os motivem - a derrubada da tirania ou o fim da guerra. Isso, ao menos, é o que a experiência ensina.

Embora esses eventos remontem a cem anos, o temor da volta da tirania é uma constante na Atenas democrática e uma expressão disso é o alto apreço dedicado aos tiranicidas Harmódio e Aristogíton, cujas estátuas inspiram a resistência dos velhos (vv. 631-634). Em 411, o cenário político justificava toda apreensão. Lisístrata é encenada na antevéspera do golpe oligárquico que levou os Quatrocentos ao poder, o que torna o discurso dos homens um alerta à cidade.

A rebelião das mulheres é uma ameaça à ordem estabelecida. Os velhos do coro, retomando a linha de pensamento do Probulo, que havia declarado que a guerra não diz respeito às mulheres (vv. 520-521; 587-588), consideram intolerável que elas aconselhem 
os cidadãos e falem "sobre o escudo de bronze" (v. 626-627). Eles também têm em vista outro perigo que a subversão pode gerar. Tirania de Hípias é uma expressão usada para designar a posição sexual em que a mulher se coloca sobre o homem e o conduz como o cavaleiro ao cavalo ${ }^{4}$. Ao tomar o ponto mais alto da cidade, ou seja, a acrópole, as mulheres ficam por cima dos homens, o que sugere aos velhos do coro que elas teriam a ambição de tomar as rédeas também na cama. A isso eles respondem prometendo levar "o punhal no ramo de mirto" (v. 632), jogando com o sentido obsceno de uma popular canção em louvor aos tiranicidas - camufladas em ramos de mirto, uma metáfora para o púbis, as armas usadas contra Hiparco são símbolos fálicos evidentes ${ }^{5}$. A questão sexual, apenas aludida aqui, será tematizada plenamente na segunda sizígia epirremática, examinada adiante.

Nesse contexto a referência à estátua de Aristogíton (v. 633) é bastante coerente e até mesmo óbvia. Afinal, juntamente com Harmódio, é ele ora o campeão da liberdade, um herói da democracia, ora o amante exemplar, protagonista de uma relação passional em as mulheres estão excluídas. Não se pode deixar de notar que, dentre os dois amantes, os velhos coreutas escolhem o que mais se ajusta ao seu physique de rôle, embora com isso tenham deixado passar um bom motivo de risadas, caso se equiparassem ao belo adolescente (a razão disso, espero, se explicará logo adiante). Mas como a ação dos tiranicidas era amplamente conhecida e no final do século $\mathrm{V}$ já adquirira contornos lendários, para evocar o personagem e seu ato não seria necessário mencionar o monumento erigido em sua memória. Se o coro o faz, é porque o monumento em si e não apenas o ato que ele evoca são parte da mensagem. Voltemo-nos então para o grupo escultórico.

Pausânias (I, 8.5), na visita que faz à ágora ateniense, defronta-se com dois pares de estátuas dedicadas aos tiranicidas. As mais antigas, obra de Antenor, tendo sido pilhadas por Xerxes durante a invasão da cidade, foram posteriormente devolvidas por Antíoco I. As mais recentes, esculpidas por Crítios, foram fundidas logo após o saque persa (477-476) para substituir as anteriores - informação que Pausânias não dá. Embora, até onde se pode afirmar, não houvesse diferenças entre os dois monumentos, o coro da Lisístrata se refere às últimas.

Cruzando as informações de Pausânias, que as menciona entre o Templo de Ares e o Odeon, com o testemunho de Arriano em sua Anábase de Alexandre (III, 16. 7-8) e com dados oriundos das escavações empreendidas pela Escola Americana em Atenas, podemos situá-las com relativa segurança na Ágora, próximas à Via Panatenaica, opostas ao Metron ${ }^{6}$ (fig. 1). Elas ocupariam, portanto, o coração da ágora ateniense, um espaço aberto, denominado orquestra, que, exceto pelo Altar dos Doze Deuses, não era edificado no século $\mathrm{V}$ a.C., não estando muito distantes do Leocoreion, onde o atentado contra Hiparco teria sido perpetrado ${ }^{7}$.

Nem o par de Antenor nem o de Crítios sobreviveram até os dias do hoje, provavelmente tendo conhecido o mesmo destino de muitas estátuas em bronze: ser derretidas para servir de munição. Felizmente, conhecemos sua aparência graças a reproduções em vasos, moedas, lamparinas e, sobretudo, cópias romanas - com destaque para o grupo pertencente ao Museo Nazionale de Nápoles (fig. 2) ${ }^{8}$. Sua identificação é possível, já que eram raros tanto o tema quanto a presença de grupos escultóricos no período em questão.

Os escultores registraram o momento em que Harmódio e Aristogíton, lado a lado, desembainharam seus punhais para desferir o ataque contra Hiparco, conferindo grande 
dramaticidade ao grupo. Aristogíton, citado pelo coro da Lisístrata, traz a arma na mão direita, mantendo paralelos o braço e a perna direitos, esticados para trás. O braço esquerdo, do qual pende o manto, está erguido para frente à altura do ombro, a mão segura a bainha e a perna está dobrada para frente, como que no impulso para o ataque (fig. 3).

A mera descrição da pose que Aristogíton assume no grupo escultórico já nos sugere uma primeira razão para o coro referir-se ao monumento. Os versos em que a menção aparece coincidem com o final do epirrema e nada mais apropriado para fechar a fala do que acompanhá-la de uma coreografia impactante. O coro deixa claro pelo uso do verbo í $\sigma \tau \eta \mu$ (e do advérbio $\hat{\omega} \delta \varepsilon$ (v. 634) que pretende imitar Aristogíton (v. 631-634):

Mas sobre mim não exercerão a tirania, pois estarei de vigília e daqui para frente levarei o punhal no ramo de mirto, acamparei na praça do mercado, em armas, ao lado de Aristogíton, e nesta posição ficarei ao lado dele ( $\left.\omega \delta \varepsilon \theta^{\star} \varepsilon \dot{\varepsilon} \sigma \tau \eta^{\prime} \xi \omega \pi \rho^{\prime} \alpha u^{\tau} \tau o ́ v\right)$.

Ao enunciar sua intenção, assumiria a mesma posição marcial, só que o desfecho seria inesperado e cômico, uma vez que nem a mão esconderia um punhal nem o golpe visaria um tirano. Ao ilustrar o último verso com o movimento de trazer à frente o braço direito, o coro concentraria toda a sua agressividade no soco desferido contra a líder do coro feminino, uma velha senhora, marcando toda a desproporção entre o modelo imitado e os imitadores (v. 635):

Vou dar um soco no queixo desta velha, a quem os deuses detestam.

Do ponto de vista da trama dramática, a menção do monumento aos tiranicidas equivale a uma declaração de posse da Ágora por parte dos homens - note-se o emprego do

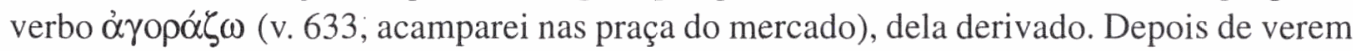
falhar sua tentativa de recuperar a Acrópole no agon que antecede esta parábase, o coro masculino ocupa a praça do mercado, o único local da cidade capaz de rivalizar com a colina sagrada, pois os edifícios que a cercavam abrigavam órgãos administrativos, arquivos, tribunais e templos, além dos estabelecimentos comerciais propriamente ditos. Ali os homens pretendem estabelecer seu quartel-general para resistir ao que, sob sua ótica, constitui um golpe de estado feminino.

Não deve passar desapercebido que a intenção de acampar aos pés de Aristogíton, reconhecendo nele um herói da democracia, serve de provocação aos Alcmeônidas, como também o fora a dúbia menção a Clístenes alguns versos acima. A razão disso pode estar na percepção do interesse de um de seus membros, Alcibíades, na desestabilização do regime democrático - de fato, a essa altura ele já trabalhava para a instalação da oligarquia. Essa ilustre família ateniense nunca teve interesse em alimentar o prestígio dos tiranicidas, pois, à medida que ele crescia, ofuscava a campanha de Clístenes contra Hípias. Assim, estabeleceu-se uma guerra de símbolos em Atenas, em que o heroísmo dos tiranicidas era evocado por Temístocles e aliados para tentar diminuir a influência do grupo rival. Como nota Francis (Francis, 1990, p. 68), os símbolos desempenhavam um papel importante na propaganda 
política no período que sucede às Guerras Médicas, o que pode ser comprovado na reconstrução da cidade.

Por volta de 470, os atenienses empreenderam um vasto programa de reurbanização levando em conta, sobretudo, a restauração do que fora destruído pelos persas durante o saque de 480. Além disso, durante o século V a.C., a Ágora foi dotada de importantes edifícios como, por exemplo, a Stoa Poikile e o Templo de Hefesto. Essas novas construções, assim como os monumentos que os cercavam, entre eles o novo grupo de esculturas dedicado aos tiranicidas, visavam a celebrar a vitória de Atenas sobre os bárbaros. Assim, o novo monumento para Harmódio e Aristogíton na Ágora ganha em significado: se a geração anterior extinguiu a tirania, a atual derrotou os Persas, os tiranos do mundo, a quem Hípias teria recorrido para tentar retomar o poder ${ }^{9}$. Assim, as armas desembainhadas pelos tiranicidas se tornam uma advertência tanto para os inimigos internos quanto para os externos.

A escolha dos tiranicidas de Crítios como símbolo de resistência dos velhos atenienses revela, portanto, toda a sua perplexidade diante dos acontecimentos. Como enquadrar a ação das mulheres? Se, por um lado, a tomada da Ácropole remete à tirania de Hípias, portanto a um episódio histórico, outra forma de compreendê-la é recorrendo a um modelo mítico, a invasão de Atenas pelo inimigo bárbaro, as Amazonas, que será plenamente desenvolvida na segunda sizígia epirremática.

\section{A Amazonomaquia de Micon}

O coro masculino retoma a palavra com uma nova exortação para que se dispam. Dessa vez parece que o propósito é dar uma demonstração de virilidade (vv. 661-662, colhões; vv. 663-666, homem deve cheirar a homem), prenunciando a mudança de ênfase no discurso do político para o erótico (vv. 658-681):

Isso não é um desaforo,

e dos grandes? E acho que não vai ficar só nisso!

Vamos, deve rechaçar isso o homem que tenha colhões.

Vamos, dispamos a túnica, já que o homem com $\mathrm{H}$ deve

já de cara cheirar a homem e não fica bem estar enrolado.

Vamos, pés-brancos, conduzi-nos,

nós que até o Lipsídrion

chegamos, quando ainda éramos jovens.

Agora, agora é preciso rejuvenescer, dar asas

a todo o corpo e sacudir para longe esta velhice.

Se um de nós lhes der uma oportunidade, ainda que mínima, nada escapará do trabalho destas mãos perfumadas, mas até barcos construirão e tentarão ainda combater e navegar contra nós, como Artemísia. 
Quando se voltam para a montaria, risco da lista os Cavaleiros, pois o mais hábil ginete e o que se mantém melhor montado é a mulher. Ela não escorregaria ainda que um dispare! Observe as Amazonas que, a cavalo, lutando com homens, Micon pintou. Ao contrário, seria preciso, pegar todas e no tronco prender-lhes o pescoço.

Os homens retomam ao tema da expulsão dos tiranos, procurando, ao mesmo tempo, voltar no tempo e recuperar o vigor da época em que lutaram em Lipsídrion contra as tropas de Hípias. Toda a passagem é cômica porque, para ter tomado parte nesses eventos, eles deveriam estar com cento e vinte anos pelo menos, idade suficiente para, note-se, serem contemporâneos de Aristogíton. É claro que esse episódio, como as batalhas de Maratona e de Salamina, não é meramente histórico, mas pertence à mitologia política da cidade. Notese, no entanto, que as forças contrárias à tirania, lideradas pelos Alcmeônidas, foram derrotadas nessa ocasião. Ao recordar um fracasso, por mais revestido de heroísmo que fosse, o coro retoma o tom provocativo anteriormente manifestado contra os integrantes desse clã.

Deixando as lutas internas de lado para abordar as campanhas contra os bárbaros, a ameaça que as mulheres representam é ilustrada com um exemplo histórico e outro mitológico. Artemísia, a rainha cária que lutou ao lado de Xerxes contra os gregos, é uma prova da capacidade das mulheres dominarem a arte da navegação, na qual os atenienses eram mestres. As Amazonas, guerreiras lendárias que invadiram Atenas e tomaram o Arerópago antes de investir contra a Acrópole, onde foram derrotadas pelos atenienses liderados por Teseu, mostram a habilidade feminina na equitação, arte restrita aos homens. O mito que narra sua expulsão da Ática, por celebrar a uma só vez a superioridade da cidade e do sexo masculino, era muito apreciado e decorava importantes prédios públicos como o Partenon, o Teseion e a Stoa Poikile. Comum a ambas, Artemísia e Amazonas, é o talento para a guerra e a hostilidade contra os atenienses.

Essa passagem é rica também em alusões obscenas que se referem sempre à posição em que a mulher se põe sobre seu parceiro, navegando-o como Artemísia ou cavalgando-o como as Amazonas. Segundo Henderson (Henderson, 1991, § 263, § 267, § 270, § 274, § 277), esse comportamento, associado a prostitutas, não era tolerado nas esposas. Com isso, os velhos retomam o sentido ambíguo da expressão "tirania de Hípias", insistindo que a atitude das mulheres no plano público tem implicações sobre sua conduta privada. Como castigo eles propõem que elas sejam presas ao tronco, ou seja, imobilizadas, ficando à mercê de seus algozes (vv. 680-681).

Tal como ocorre no primeiro epirrema, o coro não se contenta em mencionar apenas a lenda das amazonas, mas refere-se a uma de suas várias representações nas artes visuais: a amazonomaquia de Micon. Apesar de declinado o nome de seu pintor, a identificação do monumento que a abriga não é segura. Sabemos sobre Micon que, juntamente com Polignoto, foi um dos pintores de maior expressão do período que sucede às invasões persas, tendo sido encarregado por Címon de decorar diversos monumentos em Atenas. Dois dentre eles representariam a batalha de Teseu contra as Amazonas: a Stoa Poikile e o Teseion. 
A Stoa Poikile se situava no limite norte da Ágora e devia sua denominação à sua decoração, seja interna, aos quatro murais que abrigava, seja externa, à fachada policromática (fig. 1). Segundo Pausânias (I, 15.1-3), estavam ali representados o confronto entre atenienses e espartanos em Oinoe; o combate entre os atenienses, comandados por Teseu, e as Amazonas; Ajax e Cassandra diante dos chefes gregos após o saque de Tróia e a batalha de Maratona. Embora Pausânias não registre a identidade dos muralistas, Plutarco, em sua biografia de Címon (Cimon, 4, 6-7), afirma que a autoria da cena troiana é de Polignoto.

A localização do Teseion é incerta, mas Pausânias deixa claro que o santuário que Címon fez erigir para abrigar os ossos do herói ficaria nas proximidades da Ágora, junto ao ginásio Ptolomaico (I, 17. 2). O mais provável é que se encontrasse logo após o pórtico sudeste da Ágora, na direção da Acrópole ${ }^{10}$. Como observa Francis (Francis, 1990, p. 49), o sítio seria muito apropriado, uma vez que as Amazonas teriam acampado no Areópago antes de subir até a Acrópole, planejando a morte de Teseu. Ora, nas proximidades, os restos mortais do herói seriam um manifesto da derrota feminina e uma advertência contra novas ofensivas.

Nele, estariam retratados três feitos de Teseu: a amazonomaquia, a centauromaquia e o mergulho ao fundo do mar - esse último foi atribuido por Pausânias a Micon (I, 17.3). Há ainda a hipótese de que houvesse um quarto mural que retrataria Teseu no Hades, mas o testemunho de Pausânias não a sustenta ${ }^{11}$. A atribuição de um dos murais a Micon por Pausânias parece indicar que os outros seriam também de sua autoria; no entanto, esse depoimento não é aceito unanimamente, já que uma passagem, tardia e corrompida, notese, atestaria a participação de Polignoto nesse projeto ${ }^{12}$.

A analogia com a pintura cerâmica é um dos poucos recursos que restam para tentar decifrar essa questão. Duas crateras, ambas datadas do segundo quartel do século V a.C. e provenientes da Itália, parecem estar diretamente relacionadas aos murais do Teseion: uma, a do Pintor dos Nióbidas, retrataria em uma de suas faces Teseu no Hades (fig. 4); outra, a do Pintor dos Sátiros Lanudos, tem por tema uma Centauromaquia e uma Amazonomaquia (fig. 5). Ambas refletem características associadas ao estilo de Polignoto e Micon, como a disposição das figuras em vários níveis, representação parcial de algumas delas, sua expressividade. Nos dois vasos se nota uma particularidade intrigante, cuidadosamente analisada por Barron (Barron, 1972), a presença de uma quarta divisão muscular, anatomicamente incorreta, na cavidade abdominal (fig. 6 e 7). Como esse detalhe não se repete nas demais obras atribuídas a esses pintores, tudo leva a crer que tivessem um mesmo modelo e a temática aponta para o Teseion.

O exame das crateras parece depor contra a autoria da amazonomaquia do Teseion por Micon, apesar do parecer favorável de Boardman (1966, p. 122). Como nota Robertson (1975, p. 256), nos dois casos está ausente a representação da aventura submarina do herói, única cuja execução foi explicitamente a ele atribuída. Barron (1972, p. 44) observa também que, sendo Micon um bem sucedido escultor de atletas, seria de se estranhar que ele cometesse erros anatômicos em seus murais. Em seu favor, no entanto, Robertson cita a sua notória preferência por cenas movimentadas e de batalha, por oposição a Polignoto, que apreciava as mais calmas. Micon também se habilita enquanto pintor de Amazonas e Centauros graças à sua fama de bom pintor de cavalos, embora, e isso é bem curioso, insis- 
tisse em dotá-los de uma pálpebra inferior - o que nos faz pensar se estas não seriam falhas intencionais, que permitiriam o reconhecimento do seu autor à maneira de uma assinatura ${ }^{13}$. Diante desse quadro, forçosamente, é preciso declarar a questão inconclusa.

A qual das duas pinturas o coro estaria se referindo? A Stoa Poikile conta com grandes defensores, como Henderson (in Aristophanes, 1990, p. 160) e Robertson (1975, p. 243), que, no entanto, não exclui a possibilidade de Micon ter sido o autor dos dois murais, assim como Calame (1990, p. 408). De fato, um escólio aos versos 678-679 de Lisístrata testemunha a favor da Stoa Poikile, embora não fique claro se o escoliasta se baseou em alguma fonte concreta para fazer tal afirmação ou se, como nós, conjecturava ${ }^{14}$.

Se, por um lado, a localização da Stoa Poikile na Ágora favorece a identificação de seu mural como o referido pelo coro de Lísístrata (afinal, estaria ao alcance dos olhos dos coreutas que fincam pé na orquestra ao lado dos tiranicidas), a do Teseion, entre a Ágora e a Acrópole, também depõe a seu favor, pois os homens têm como interlocutor dessa parábase, justamente qualificada de agonística ${ }^{15}$, não apenas os espectadores, mas as mulheres do semicoro rival que montavam guarda nos Propileus. Tudo faria ainda mais sentido, caso os dois murais fossem de Micon, pois os dois edifícios, estando nos limites norte e sul da Ágora, marcariam o território masculino - os coreutas dizem: "observe as Amazonas que Micon pintou”, o que pode apontar para mais de uma pintura.

De qualquer forma, os dois murais têm em comum a presença de Teseu, um símbolo da supremacia ateniense em sua luta contra os bárbaros, sejam eles persas, amazonas ou centauros, e, por trás do herói, a de Címon. O filho de Miltíades é um dos maiores responsáveis pela proliferação da imagem de Teseu após as Guerras Médicas, tendo organizado uma expedição a Skyros para resgatar os ossos do herói, erigido o Teseion para abrigá-los, pondo-o em evidência em dois dos murais da Stoa Poikile, a amazonomaquia e a Batalha de Maratona, onde é retratado saindo da terra para lutar com os atenienses ${ }^{16}$. Mas a faceta mais interessante dessa associação está na transformação do herói num defensor da democracia, verificada na sua assimilação aos tiranicidas.

Tanto numa série de vasos, cujo protótipo foi analisado por Smith no final do século passado, quanto nos frisos do templo de Hefesto na Ágora (fig. 1), Teseu é representado ora como o Aristogíton, ora como o Harmódio de Crítios ${ }^{17}$. Barron (1972, p. 39-40), analisando a amazonomaquia e a centauromaquia do Pintor dos Sátiros Lanudos, observa a semelhança entre a pose dos combatentes gregos, entre eles o herói, e a dos tiranicidas (fig. 8), lembrando também que o grupo escultórico de Crítios fora instalado na Ágora um ano antes da expedição de Cimon a Skyros, o que aumentaria a propabilidade que o mesmo se verificasse no Teseion. Francis (1990, p. 69) mostra como interessava a Címon, cuja árvore genealógica remontava ao herói, fazer de Teseu o tiranicida arquetípico, de forma a enfraquecer a influência política de Temístocles e reforçar o seu próprio prestígio e o dos Alcmeônidas, a quem estava ligado por casamento.

A parábase de Lisístrata parece corroborar a hipótese de Barron sobre um Teseu tiranicida nas representações murais da amazonomaquia, já que a pintura de Micon está citada no antepenúltimo verso da segunda sizígia epirremática, ocupando a mesma posição que a referência à escultura de Crítios na primeira. Se a menção a Aristogíton, como sugeri, 
implicaria um movimento coreográfico mimético que serviria de fecho à primeira intervenção masculina, a presença subliminar do Teseu tiranicida de Micon possibilitaria a retomada do mesmo passo, caracterizando bem o paralelismo entre os dois antepirremas - inclusive no que diz respeito ao toque de humor final em que o golpe de morte se transformaria na mímica da prisão das mulheres do coro rival no tronco (vv. 680-681). Ao mesmo tempo, o coro teria a oportunidade de fazer do herói nacional, Teseu, um aliado na luta contra a tirania, não somente a representada pelas mulheres agrupadas na Acrópole, mas pelos oligarcas, cujo golpe estava em gestação. Cercados por representações de Teseu, a norte e sul nos murais monumentais, a oeste nos frisos do Templo de Hefesto, os velhos atenienses do coro ganham forças para enfrentar o exército de Palas posicionado na Acrópole e as ameaças que ele evoca.

Como conclusão, gostaria de ressaltar a relação de complementaridade entre palavra e imagem na Grécia clássica. A referência a dois importantes monumentos da cidade de Atenas na parábase da Lisístrata vai além da mera indicação espacial, situando a ação na Ágora, mas se revela agregadora de sentido ao discurso do coro, pois, como portadora da história cultural de uma comunidade, toda imagem revela a sua ideologia. Como nota Francis (Francis, 1990, p. 73), obras de arte, como os murais da Stoa Poikilé ou do Teseion e o grupo escultórico dos tiranicidas, por exemplo, podem adquirir para o seu público "a força da história e o augúrio da revelação", já que os monumentos da cidade têm a capacidade de tornar os mitos tangíveis e críveis, inserindo-os incondicionalmente nas vidas dos cidadãos de forma a moldar suas crenças e guiar seu comportamento. Na Lisístrata vemos esse processo em ação na maneira como o coro masculino se apropria dos monumentos da Ágora como símbolos de resistência contra a tirania, agindo sob sua inspiração.

\section{Notas}

1 - Sobre a relação entre as duas tramas da peça, cf. Henderson (1980, p. 185-186), Loraux (1984). Hulton (1972, p. 36) concede que os dois planos se complementam teoricamente, ainda que não o façam no âmbito da ação. Sobre o caráter transicional da parábase, cf. Hubbard (1991, p. 194-195).

2 - As traduções da Lisístrata são da autora.

3 -Cf. Heródoto (V, 55-65; VI, 123), Tucídides (VI, 53-59) e Aristóteles (A Constituição dos Atenienses, XVIII-XX). Bowie (1993, p. 195-197) sugere que os eventos que marcaram a destituição de Hípias teriam fornecido um dos modelos para a estruturação do enredo de Lisístrata.

4 - Cavalo (hippos) é metáfora para o pênis e cavalgada para o ato sexual; Cf. Henderson (1991: § $274 ; 277)$.

5 - Cf. Henderson (1990, p. 153).

6 - Cf. Wycherley (1975, p. 118).

7 - Sobre a ágora cf. American School of Classical Studies at Athens (1986). Sobre a morte de Hiparco, $c f$. Tucídides (VI, 57); Aristóteles (XVIII, 3).

8 - Para iconografia cf. Richter (1970, figuras 565 a 577).

9 - Cf. Francis (1990, p. 68).

10 - Cf. Wycherley (1959, p. 155). 
11 - A favor da hipótese, cf. Barron (1972) e Robertson (1975, p. 245); contra, cf. Francis (1990, p. 50-51), para quem o fato de o viajante grego abordar detalhes da morte de Teseu se justifica por estar diante do sepulcro do herói.

12 - Harpokration, no verbete dedicado a Polignoto, no Lexicon, associa o pintor a Stoa Poikile, ao tesouro (thesauroi, corrigido para Theseos hieroi) e ao Anakeion. Cf. Pollitt (1990, p. 127).

13 - Sobre Micon e os cavalos, cf. Eliano, Natura Animalium, 4. 50 (in Pollitt, 1990, p. 142).

14 - Cf. Pollitt (1990, p. 141-142).

15 - Henderson (1990, p. 148-149) vai chamá-la de debate parabático, notando que ela é tão ou mais agonística que o próprio agón, que é de natureza expositiva. Russo (1994, p. 168) se refere a ela como parábase agonística.

16 - Sobre o papel de Címon na transformação de Teseu em símbolo de Atenas, cf. Calame (1990, p. 416-418).

17 - Cf. Smith (1881, p. 61); Thompson (1962, p. 345-346).

\section{Referências bibliográficas}

AMERICAN SCHOOL OF CLASSICAL STUDIES AT ATHENS. Petit guide de l' agora d'Athènes. Album n ${ }^{\circ} 16$ des fouilles de l'agora d'Athènes. Atenas: American School of Classical Studies at Athens, 1986.

ARISTOPHANES. Lysistrata. Edited with introduction and commentary by J. Henderson. Oxford: Clarendon Press, 1990.

ARISTÓTELES. A constituição de Atenas. Edição bilíngüe com tradução e comentários de Francisco Murari Pires. São Paulo: HUCITEC, 1995.

ARRIAN. Anabasis Alexandri. Edited and translated by Ilif Robson. Cambridge/ Massachusetts: Harvard University Press, 1956.

BARRON, J. New light on old walls. The murals of the Theseion. Journal of Hellenic Studies, 92, p. 20-45, 1972.

BOARDMAN, J. L' art grec. Paris: Flammarion, 1966.

BOWIE, A. Aristophanes: myth, ritual and comedy. Cambridge: Cambridge University Press, 1993.

CALAME, C. Thésée et l'imaginaire athénien. Légende et culte en Grèce antique. Lausanne: Éditions Payot Lausanne, 1990.

DAVIE, J. N. Theseus the king in fifth-century Athens. Greece \& Rome, 29, p. 25-33, 1982.

FRANCIS, E. D. Image and idea in fifth-century Greece. Art and literature after the Persians Wars. London: Routledge, 1990.

HENDERSON, J. Lysistrata: the play and its themes. In: (Org.) Aristophanes: Essays in interpretation, Cambridge: Cambridge University Press, 1980, p. 153-218.

The maculate muse. Obscene language in Attic comedy. New York/Oxford: Oxford University Press, 1991 (*1975).

HERODOTE. Histoires. Texte établi et traduit par Ph.-E. Legrand. Paris: Les Belles Lettres, 1970. 
HUBBARD, T. The mask of comedy: Aristophanes and the intertextual parabasis. Cornell Studies in Classical Philology, 51, 1991.

HULTON, O. The women on the Acropolis: a note on the structure of the Lysistrata. Greece \& Rome, 19, p. 32-36, 1972.

LORAUX, N. L'acropole comique. In: Les enfants d'Athéna. Idées athéniennes sur la citoyenneté et la division des sexes. Paris: Éditions de la Découverte, 1984, p. 157. 196.

PAUSANIAS. Description de la Grèce. Livre I: L'Attique. Texte établi par Michel Casevitz, traduit par Jean Pouilloux et commenté par François Chamoux. Paris: Les Belles-Lettres, 1992.

POLLITT, J. J. The art of ancient Greece. Source and documents. London: Cambridge University Press, 1990 (1965).

PLUTARQUE. Cimon. In: ___ Vies VII. Texte établi et traduit par Robert Flacelière et Émile Chambry. Paris: Les Belles Lettres, 1972.

RICHTER, G. The sculpture and sculptors of the Greeks. New Heaven, 1970.

ROBERTSON, M. A history of Greek art. London: Cambridge University Press, 1975.

RUSSO, C. Aristophanes an author for the stage. Tradução de Kevin Wren. Routledge: London and New York, 1994.

SMITH, C. Kylix with exploits of Theseus. Journal of Hellenic Studies, 2, p. 57-64, 1881.

THOMPSON, H. A. The sculptural adornment of the Hephaisteion. American Journal of Archaeology, 66, p.339-347, 1962.

THUCYDIDE. La guerre du Péloponese. Texte établi et traduit par Jacqueline de Romilly. Paris: Les Belles Lettres, 1968.

WOODFORD, S. More light on old walls: the Theseus of the centauromachy in the Theseion. Journal of Hellenic Studies, 94, p. 158-165, 1974.

WYCHERLEY, R. E. The temple of Hephaistos. Journal of Hellenic Studies, 79, p. 153$163,1959$.

. Two notes on Athenian topography. Journal of Hellenic Studies, 95, p. 117-121, 1975.

DUARTE, Adriane da Silva. The monuments of Athens in Aristophanes's Lysistrata. Classica, São Paulo, 13/14, p. 173-187, 2000/2001.

ABSTRACT: In Aristophanes' Lysistrata, Athenian monuments are important to the development of comic plot, particularly the Acropolis, besieged by the women, which plays a crucial role in the heroine's plans to put an end to the war between Athenians and Spartans. The men, expelled 
from the Acropolis, set themselves in the Agora and chose as major symbol of their resistance the tyrannicides' sculpture and Micon's Amazonomachy. This paper intends to investigate why the men's chorus elects those monuments to illustrate its speech.

KEYWORDS: Greek comedy; Aristophanes; Lysistrata; Athenian agora; Greek art; Amazonomachy; tyrannicides; Critios; Micon; iconographic tradition.

\section{Agradecimento}

Agradeço a Maria Cecília Miranda Coelho e a Haiganuch Sarian por me haverem propiciado acesso a textos importantes para a elaboração deste artigo

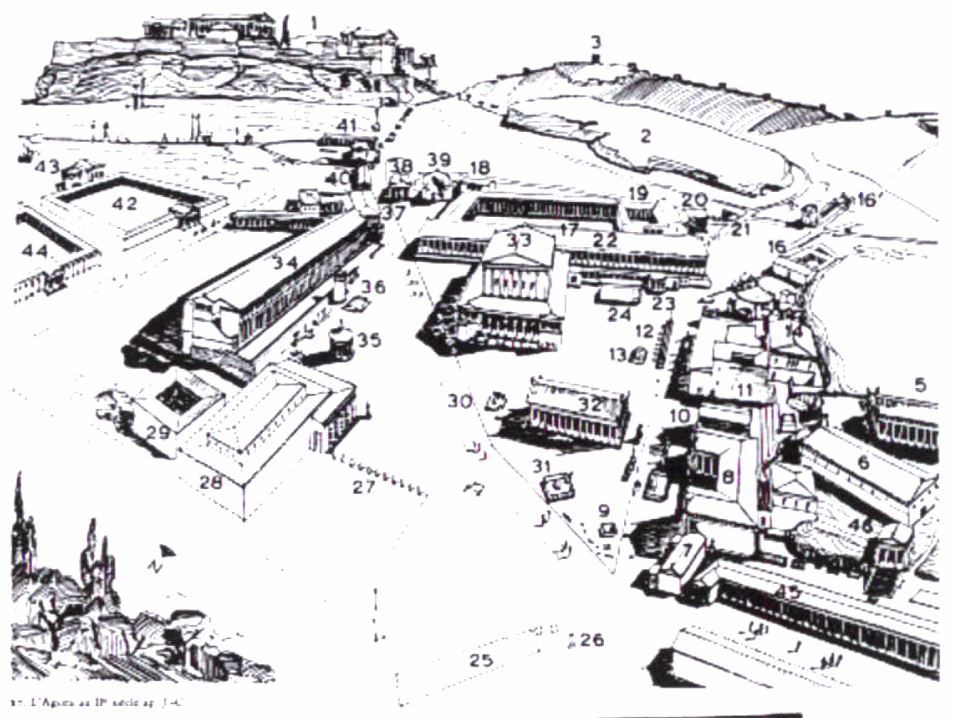

Fig. 1 - Agora ateniense, II d.C.. No limite norte, ficaria a Stoa Poikile (25), enquanto o Teseion estaria nas proximidades do Pórtico Sudeste (40). A estátua dos tiranicidas se situaria diante do Templo de Ares (32). Sobre a colina, vê-se o Templo de Hefesto (5). Desenho de J. Travlos para a American School of Classical Studies in Athens (1986, p. 16-17). 


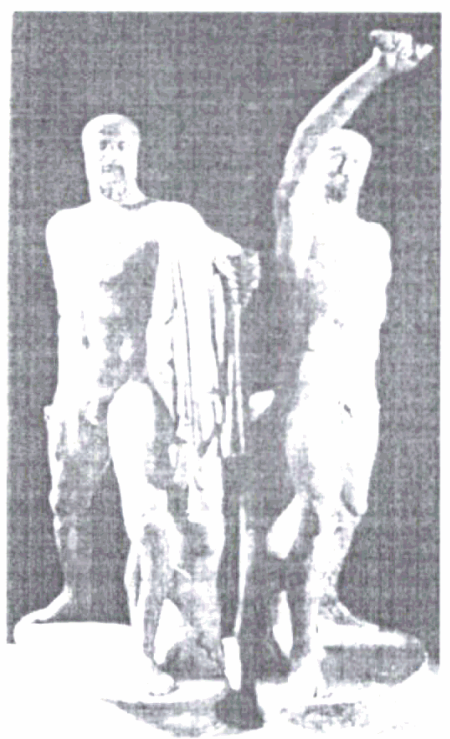

Fig. 2 - Grupo dos tiranicidas. Museo Nazionale, Nápoles.

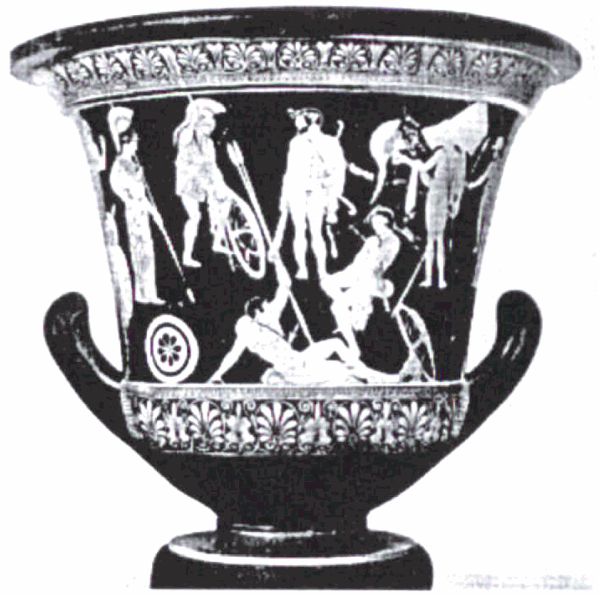

Fig. 4 - Teseu e Pirítoo no inferno. Cílicecratera atribuída ao Pintor dos Nióbidas. Meados do séc. V a.C. Louvre, Paris.

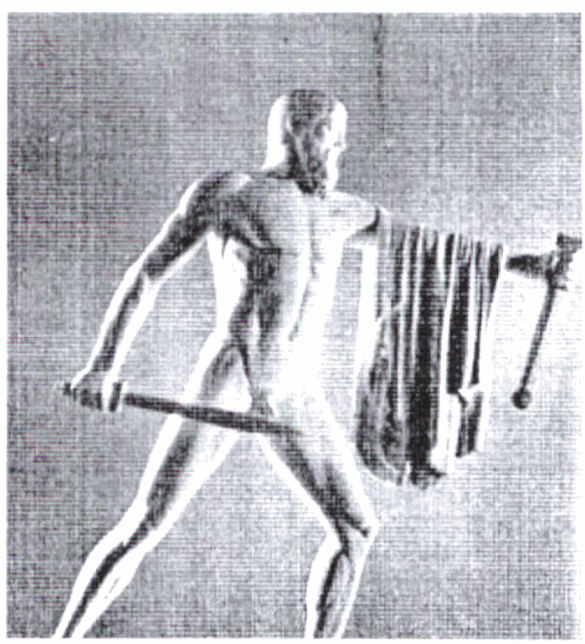

Fig. 3 - Aristogiton. Museo Nuovo, Roma.

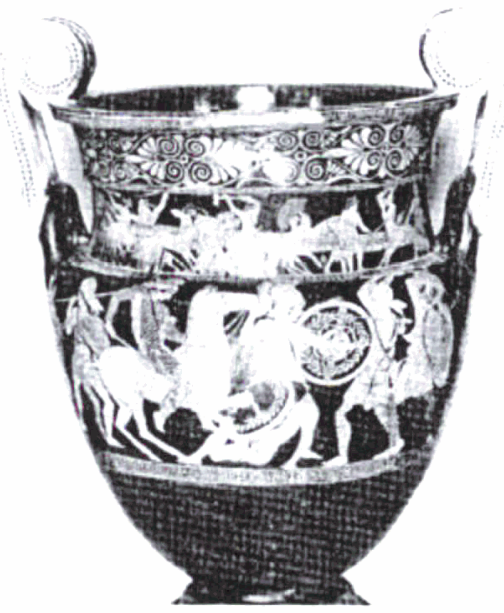

Fig. 5 - Amazonomaquia e, no alto, centauromaquia. Cratera com volutas atribuída ao Pintor dos Sátiros Lanudos. Cerca de 440 a. C. Metropolitan Museum of Art, New York. 


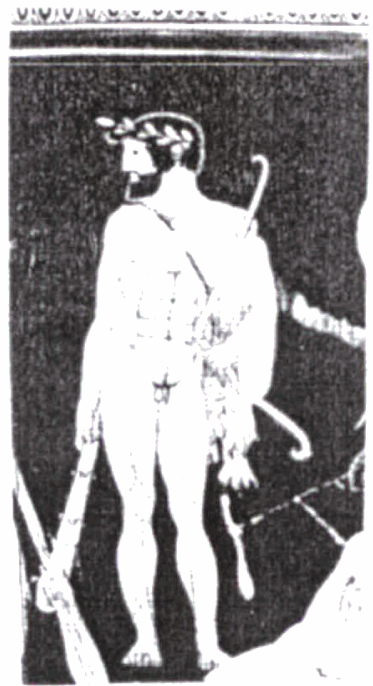

Fig. 6 - Detalhe da fig. 4

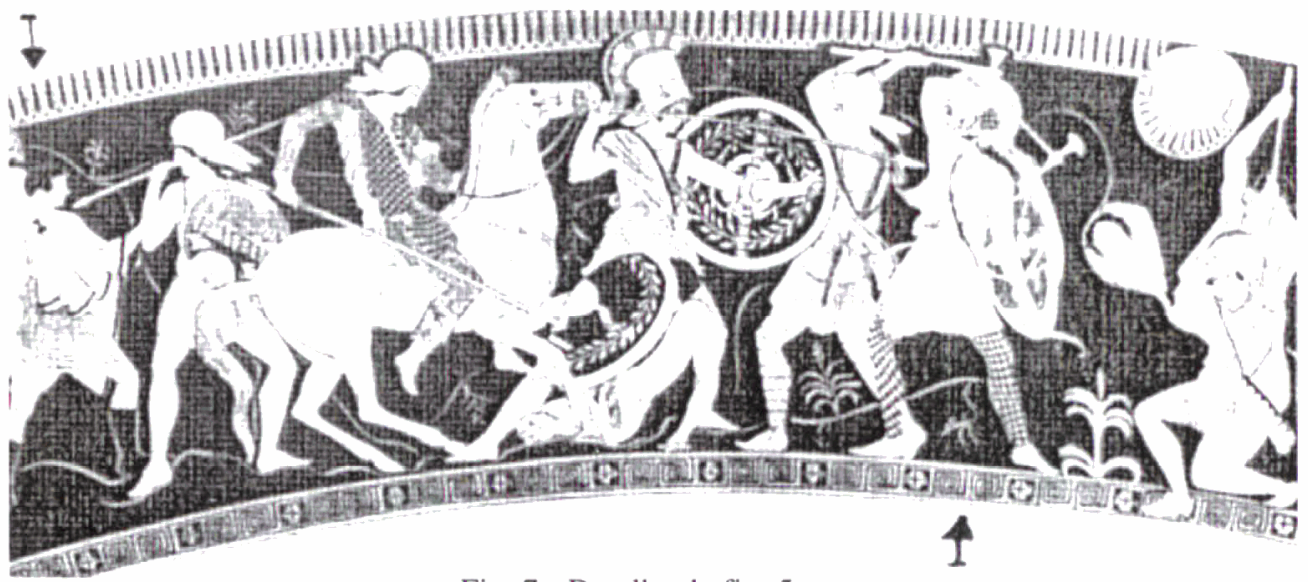

Fig. 7 - Detalhe da fig. 5
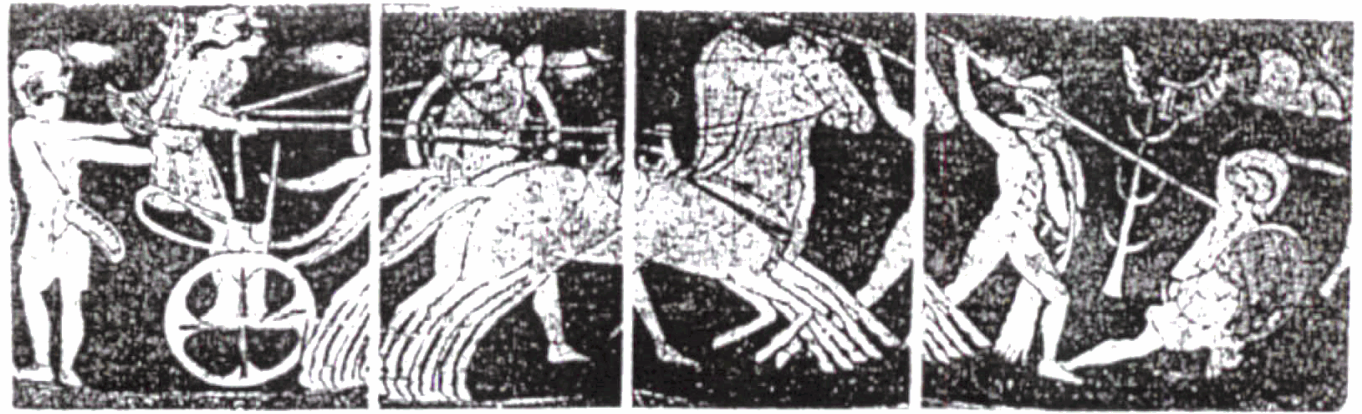

Fig. 8 - Detalhe da fig. 5 